\title{
Effect of Time of Pollination and Period of Pollen Storage on Seed Yield and Quality of Brinjal Hybrid (Solanum melongena L.)
}

\author{
S.M. Veeresha, Shantappa Tirakannanavar*, Dileep Kumar Masuti, R.C. Jagadeesha \\ Ratnakar M. Shet and V. Harshavardhan Gowda
}

\author{
Kittur Rani Channamma College of Horticulture, Arabhavi-591 218, University of \\ Horticultural Sciences, Bagalkot-587102, Karnataka, India
}

*Corresponding author

\section{A B S T R A C T}

\begin{tabular}{|l|}
\hline Ke y w o r d s \\
Hybrid, Pollen, \\
Emasculation, \\
Pollination, \\
Germination, \\
Vigour \\
\hline Article Info \\
\hline Accepted: \\
15 June 2018 \\
Available Online: \\
10 July 2018 \\
\hline
\end{tabular}

The experiment was conducted in randomised block design with two factors and three replications during kharif 2015 and 2016 at Kittur Rani Channamma College of Horticulture, Arabhavi. The time of pollination as one factor viz., pollination between 6.00 to $7.00 \mathrm{am}\left(\mathrm{T}_{1}\right), 7.00$ am to $8.00 \mathrm{am}\left(\mathrm{T}_{2}\right), 8.00$ to $9.00 \mathrm{am}\left(\mathrm{T}_{3}\right), 9.00$ to $10.00 \mathrm{am}\left(\mathrm{T}_{4}\right)$ and 10.00 to $11.00 \mathrm{am}\left(\mathrm{T}_{5}\right)$ and period of pollen storage as another factor viz., Pollination with fresh pollen $\left(\mathrm{P}_{1}\right)$, pollination in one day old pollen $\left(\mathrm{P}_{2}\right)$ and pollination with two day old pollen $\left(\mathrm{P}_{3}\right)$. The results revealed that the time of pollination between 9-10 am showed the highest number of crossed fruits retained per plant (11.11), per cent fruit set (42.77), fruit length $(10.53 \mathrm{~cm})$, fruit diameter $(7.48 \mathrm{~cm})$, thousand seed weight $(5.76 \mathrm{~g})$, seed yield of crossed fruits per plant (47.73 g), germination per cent (84.34\%) and vigour index (1249). Among the periods of pollen storage, the fresh pollens recorded maximum values for number of crossed fruits retained per plant $(9.80 \%)$, per cent fruit set $(39.87 \%)$, fruit length $(10.86 \mathrm{~cm})$, fruit diameter $(7.22 \mathrm{~cm})$, thousand seed weight $(5.43 \mathrm{~g})$ and seed yield $(43.25 \mathrm{~g})$ of crossed fruits per plant, germination per cent $(83.64 \%)$ and vigour index (1244).

\section{Introduction}

Brinjal (Solanum melongena L.) [2n=24] is one of the popular and commercially important vegetable crop of Indian subcontinent, belongs to the family Solanaceae. It is also called as eggplant, aubergine and guinea squash; it can be grown in different agro-climatic conditions throughout the year. In brinjal, $F_{1}$ hybrid seed set and yield are influenced by several factors like time of emasculation and pollination and crossing ratio besides use of improved seed production techniques. The most productive and desirable hybrid seed can be obtained from the female parent when there is a perfect coincidence of stigma receptivity with pollen viability of male parent. Since brinjal is mainly a self pollinated crop, pollination is done usually on the day of flower opening itself and can be continued till noon hours, though peak anthesis is seen at 8:30 to $10: 30$ 
am. But success rate of pollination varies from 50 to 70 per cent in brinjal hybrid seed production. The pollen dehiscence starts from 9.30 to 10 am and stigma receptivity is highest during anthesis. Early pollination with viable pollen may lead to poor seed setting due to non receptivity of stigma and similar is the case if flowers are pollinated very late, because of drying of stigma or loss of pollen viability. Apart from these, the excess pollens produced or unused pollens are to be stored for at least for few days for subsequent crossings without losing its viability. Therefore, time of pollination and period of pollen storage plays a key role in successful hybrid seed production. However, work pertaining to time of pollination and period of pollen storage is inadequate in brinjal. Hence, the present investigation was conducted in kharif season of 2015 and 2016 with five different times of pollination and three periods of pollen storage in refrigerator. This investigation was initiated to find out suitable time of pollination and period of pollen storage on hybrid seed yield and quality in brinjal.

\section{Materials and Methods}

The experiment was conducted at Kittur Rani Channamma College of Horticulture, Arabhavi, the seeds of both parents prior to sowing were treated with bavistin at the rate of two $\mathrm{g}$ per $\mathrm{kg}$ of seeds for getting healthy seedlings. The treated seeds of male and female parents were sown in the raised beds separately male parent was sown 10 days before the female parent sowing. It was watered alternately and plant protection measures were taken regularly as required. The bed was kept weed free with manual weeding during the nursery period. Uniform sized healthy 30 days old male and female seedlings were transplanted in two adjacent parental blocks of the crossing field. One seedling per hill was planted at inter and intra- spacing of 75 and $60 \mathrm{~cm}$. A distance of five meter was maintained between the female and male parental blocks. The experiment consists of K12 D10 36-1 as male parent and genotype K12 D10 32-5 as female parent for brinjal hybrid seed production. The experiment was conducted in randomised block design with two factors and three replications, The time of pollination as one factor viz., pollination between 6.00 to $7.00 \mathrm{am}\left(\mathrm{T}_{1}\right), 7.00 \mathrm{am}$ to 8.00 am $\left(\mathrm{T}_{2}\right), 8.00$ to $9.00 \mathrm{am}\left(\mathrm{T}_{3}\right), 9.00$ to 10.00 am $\left(\mathrm{T}_{4}\right)$ and 10.00 to 11.00 am $\left(\mathrm{T}_{5}\right)$ and period of pollen storage as another factor viz., Pollination with fresh pollen $\left(\mathrm{P}_{1}\right)$, pollination in one day old pollen $\left(\mathrm{P}_{2}\right)$, pollination with two day old pollen $\left(\mathrm{P}_{3}\right)$. The hermophrodite flowers of female parent were emasculated in the previous evening. Only the floral buds likely to open on next day morning hours were only emasculated by using the forceps, needle, scalpel, etc. Since female parent was indeterminate in growth habit, the emasculation work was restricted only to first 30 days from start of flowering period wherein flowering was at its peak. The fresh pollens extracted from male parental flowers were filled up in the plastic rings specially designed for easy pollination. At the start of blooming period, fully opened flowers were plucked from the male parental block and were collected in polythene bag in early morning hours of the crossing day. The pollen separated from anthers was filtered through muslin cloth into another cup. The extracted pollens were then transferred to plastic vials by using camel hair brush. The plastic vials were kept in a cool place for overnight period under refrigerated condition. The stigma of previously emasculated female buds was gently dipped in pollen mass of plastic ring borne on left hand forefinger. Pollination was done with fresh pollen, one day old pollen and two day old pollen at different time interval. At the end of the experiment some observations were recorded number of fruits retained per plant, per cent fruit set, fruit 
length, fruit diameter, thousand seed weight, seed yield of crossed fruits per plant, seed germination, seedling length, seedling dry weight and seedling vigor index from each treatment randomly and were analysed.

\section{Results and Discussion}

\section{Time of pollination}

\section{Fruit set, seed yield and its attributes}

The results of the experiment revealed that, pollination time was found to be significant for number of fruits retained per plant, per cent fruit set, fruit length, fruit diameter, thousand seed weight and seed yield of crossed fruits per plant, except for number of flowers pollinated per plant irrespective of period of pollen storage. On an average, the highest number of fruits retained per plant, per cent fruit set, fruit length, fruit diameter, thousand seed weight, seed yield of crossed fruits per plant were observed in the 9:00 to 10 am pollination time $(11.11,42.77 \%, 10.53 \mathrm{~cm}$, $7.48 \mathrm{~cm}, 5.76 \mathrm{~g}$, and $47.73 \mathrm{~g}$, respectively) and it was followed by 8:00 to 9:00 am pollination for number of fruits retained per plant, per cent fruit set, fruit length, fruit diameter, thousand seed weight and seed yield of crossed fruits per plant whereas all these parameters are significantly less in 6:00 to 7:00 am pollination $(8.22,33.99 \%, 9.44 \mathrm{~cm}$, $6.02 \mathrm{~cm}, 4.48 \mathrm{~g}$, and $32.86 \mathrm{~g}$, respectively).

The significant increase in seed yield per plant noticed in the 9:00 to 10:00 am pollination time may be due to its higher number of fruits retained per plant, per cent fruit set, fruit length, fruit diameter, thousand seed weight, seed yield of crossed fruits per plant. These results might also be related to prevalence of active stigma receptivity and peak pollen viability during 8:30 am and 10:30 am period in view of congenial environmental conditions. Obviously it might have to significant increase in seed yield per plant and its components at 9:00 am pollination and it might be to other pollination times. On other hand, number of fruits retained per plant, per cent fruit set, fruit length, fruit diameter, thousand seed weight, seed yield of crossed fruits per plant were the lowest in the 6:00 to 7:00 am pollination time and it might be ascribed to very early pollination where anthesis just started or may be due to environmental conditions. These results are well documented in the findings Petrova et al., (1981), Basavaraj (1992) and Chattopadhyaya (2000) and Chen (2003) in brinjal; Hazra et al., (2003) in tomato and Padda and Singh (1971) in capsicum.

\section{Seed quality parameters}

The seed quality parameters under study exhibited marked differences due to time of pollination irrespective of the period of pollen storage. Seed germination, seedling length and seedling vigor index were significantly the highest $(84.34 \%, 16.58 \mathrm{~cm}$ and 1249, respectively) in 9:00 to $10: 00$ am pollination time followed by 8:00 to 9:00 am and seedling dry weight $(13.60 \mathrm{mg})$ was highest in 8:00 to 9:00 am pollination time followed by 9:00 to 10:00 am pollination. Whereas, significantly low in 6:00 to 7:00 pm pollination time for seed germination $(78.70 \%)$, seedling dry weight $(12.17 \mathrm{mg})$ and seedling vigour index (1042). The seedling length $(14.58 \mathrm{~cm})$ was observed low in 7:00 to 8:00 am pollination time. The significant increase in seed quality parameters noticed in 9:00 to 10:00 am pollination may be due to higher fruit length, fruit diameter, thousand seed weight, seed yield of crossed fruits per plant as evident in this study and these might have produced more number of heavier and bolder seeds contributing to better seed quality. On the other hand, seed quality traits were lower in the 6:00 to 7:00 am pollination and it may be attributed to immature and thinner seeds 
obtained and from of the early pollination. These results are in corroborative with those of Petrova et al., (1981) in brinjal and Yogeesha et al., (1999) and Jolli (2004) in tomato.

\section{Period of pollen storage}

\section{Fruit set, seed yield and its attributes}

The statistical differences on fruit character and seed yield components were significant due to period of pollen storage (Table 1 and 2). Among the periods of pollen storage, the fresh pollens recorded maximum values for number of crossed fruits retained per plant $(9.80 \%)$, per cent fruit set $(39.87 \%)$, fruit length $(10.86 \mathrm{~cm})$, fruit diameter $(7.22 \mathrm{~cm})$, thousand seed weight $(5.43 \mathrm{~g})$ and seed yield $(43.25 \mathrm{~g})$ of crossed fruits per plant and it was followed by the one day old $\left(\mathrm{P}_{2}\right)$ pollens used for pollination. All these parameters were minimum in the two day old pollen $\left(\mathrm{P}_{3}\right)(9.33$, $35.59 \%, 9.06 \mathrm{~cm}, 6.41 \mathrm{~cm}, 4.63 \mathrm{~g}$ and $31.98 \mathrm{~g}$, respectively). Significant increase in seed yield per plant observed in the fresh pollen may be attributed to higher fruit set percentage, fruit length, fruit diameter, thousand seed weight and seed yield of crossed fruit per plant. It was further related to more number of matured and viable pollens which resulted in better fertilization of ovules giving rise to higher number of crossed fruits per plant, number of seeds and seed weight of thousand seeds. These results are in agreement with those of Nascimento et al., (2000) in brinjal and Chitradevi (2000) and Yogeesha et al., (1999) in tomato.

\section{Seed quality parameters}

Significant variations due to period of pollen storage was noticed for germination percentage, seedling length, seedling dry weight and vigour index (Table 3 and 4). Among the periods of pollen storage, use of fresh pollens recorded significantly the highest germination (83.64\%), seedling length (16.46 $\mathrm{cm})$, seedling dry weight $(14.39 \mathrm{mg})$ and vigour index (1244) followed by one day old pollens. All these parameters were the lowest in the two day old pollens used for pollination. The increase in seed quality parameters as observed in use of fresh pollen may be due to higher seed weight and bolder seeds of the fruits obtained from fresh pollens compare to all other treatments. Similar findings are also confirmed by Chen (2003) and Patil et al., (2003).

\section{Interaction effect}

The interaction effect between time of pollination and period of pollen storage $(\mathrm{T} x$ P) was found to be significant for most of the seed yield and quality parameters except for fruit length. All these parameters viz., number of fruits retained per plant (12:00), per cent fruit set $(44.17 \%)$, fruit diameter $(8.23 \mathrm{~cm})$, thousand seed weight $(6.13 \mathrm{~g})$, seed yield of crossed fruits per plant $(54.67 \mathrm{~g})$, were significantly higher with the interaction of time of pollination between 9 to $10 \mathrm{am} \mathrm{x}$ pollination with fresh pollens $\left(\mathrm{T}_{4} \mathrm{P}_{1}\right)$ and it was on par with $\mathrm{T}_{4} \mathrm{P}_{2}$ for per cent fruit set (43.26), fruit diameter $(8.22 \mathrm{~cm})$ and seed yield of crossed fruits per plant $(54.07 \mathrm{~g})$. Seed quality parameters viz., germination percentage, seedling length, seedling dry weight and seedling vigour index showed significant difference for the interaction of time of pollination and period of pollen storage $\left(\begin{array}{lll}T & x & P\end{array}\right)$. Higher seed quality parameters viz., germination percentage (88.26 $\%)$, seedling length $(17.63 \mathrm{~cm})$, seedling dry weight $(17.73 \mathrm{mg})$ and seedling vigour index (1391) were obtained by the interaction between the treatment combinations of $\mathrm{T}_{4} \mathrm{P}_{1}$. Similar results were reported by Patil et al., (2003) in brinjal, Jolli (2004) and Yogeesha et al., (1999) in tomato. 
Table.1 Effect of time of pollination and period of pollen storage on number of fruits retained per plant, per cent fruit set and fruit length in brinjal hybrid

\begin{tabular}{|c|c|c|c|c|c|c|c|c|c|c|c|c|}
\hline \multirow[t]{3}{*}{ Time of pollination } & \multicolumn{12}{|c|}{ Period of pollen storage } \\
\hline & \multicolumn{4}{|c|}{$\begin{array}{c}\text { Number of fruits retained per } \\
\text { plant }\end{array}$} & \multicolumn{4}{|c|}{ Per cent fruit set } & \multicolumn{4}{|c|}{ Fruit length (cm) } \\
\hline & $\mathbf{P}_{1}$ & $\mathbf{P}_{2}$ & $\mathbf{P}_{\mathbf{3}}$ & Mean & $\mathbf{P}_{1}$ & $\mathbf{P}_{2}$ & $\mathbf{P}_{3}$ & Mean & $\mathbf{P}_{1}$ & $\mathbf{P}_{2}$ & $\mathbf{P}_{\mathbf{3}}$ & Mean \\
\hline $\mathbf{T}_{1}$ & 8.00 & 8.33 & 8.33 & 8.22 & 38.04 & 32.96 & 30.98 & 33.99 & 10.13 & 9.50 & 8.70 & 9.44 \\
\hline $\mathbf{T}_{2}$ & 9.33 & 8.67 & 9.33 & 9.11 & 39.79 & 37.61 & 36.28 & 37.89 & 11.06 & 9.93 & 9.56 & 10.18 \\
\hline $\mathbf{T}_{\mathbf{3}}$ & 10.33 & 10.67 & 9.33 & 10.11 & 41.49 & 38.21 & 36.12 & 38.6 & 10.80 & 10.36 & 9.00 & 10.05 \\
\hline $\mathbf{T}_{4}$ & 12.00 & 10.67 & 10.67 & 11.11 & 44.17 & 43.26 & 40.88 & 42.77 & 11.53 & 10.76 & 9.30 & 10.53 \\
\hline $\mathbf{T}_{5}$ & 9.33 & 8.33 & 8.00 & 8.56 & 35.88 & 35.81 & 33.71 & 35.14 & 10.76 & 10.60 & 8.73 & 10.03 \\
\hline Mean & 9.8 & 9.33 & 9.33 & 9.42 & 39.87 & 37.57 & 35.59 & 37.68 & 10.86 & 10.23 & 9.06 & 10.05 \\
\hline $\begin{array}{l}\text { For comparing the } \\
\text { means of }\end{array}$ & \multicolumn{2}{|c|}{ S.Em \pm} & \multicolumn{2}{|c|}{ CD (5\%) } & \multicolumn{2}{|c|}{ S.Em \pm} & \multicolumn{2}{|c|}{ CD (5\%) } & \multicolumn{2}{|c|}{ S.Em \pm} & \multicolumn{2}{|c|}{ CD (5\%) } \\
\hline $\mathbf{T}$ & \multicolumn{2}{|c|}{0.20} & \multicolumn{2}{|c|}{0.59} & \multicolumn{2}{|c|}{0.41} & \multicolumn{2}{|c|}{1.21} & \multicolumn{2}{|c|}{0.198} & \multicolumn{2}{|c|}{0.576} \\
\hline $\mathbf{P}$ & \multicolumn{2}{|c|}{0.15} & \multicolumn{2}{|c|}{0.46} & \multicolumn{2}{|c|}{0.32} & \multicolumn{2}{|c|}{0.94} & \multicolumn{2}{|c|}{0.153} & \multicolumn{2}{|c|}{0.446} \\
\hline $\mathbf{T} \times \mathbf{P}$ & \multicolumn{2}{|c|}{0.35} & \multicolumn{2}{|c|}{1.03} & \multicolumn{2}{|c|}{0.72} & \multicolumn{2}{|c|}{2.1} & \multicolumn{2}{|c|}{0.343} & \multicolumn{2}{|c|}{ NS } \\
\hline
\end{tabular}

Period of pollen storage $(\mathrm{P})$ : $\mathrm{P}_{1}$ - Fresh pollen; $\quad \mathrm{P}_{2}$ - One day old pollen ; $\mathrm{P}_{3}$ - Two day old pollen; NS: Non Significant 
Table.2 Effect of time of pollination and period of pollen storage on fruit diameter, 1000 seed weight and Seed yield per plant in brinjal hybrid

\begin{tabular}{|c|c|c|c|c|c|c|c|c|c|c|c|c|}
\hline \multirow[t]{3}{*}{ Time of pollination } & \multicolumn{12}{|c|}{ Period of pollen storage } \\
\hline & \multicolumn{4}{|c|}{ Fruit diameter (cm) } & \multicolumn{4}{|c|}{1000 seed weight $(\mathrm{g})$} & \multicolumn{4}{|c|}{ Seed yield per plant (g) } \\
\hline & $\mathbf{P}_{1}$ & $\mathbf{P}_{2}$ & $\mathbf{P}_{3}$ & Mean & $\mathbf{P}_{1}$ & $\mathbf{P}_{2}$ & $\mathbf{P}_{3}$ & Mean & $\mathbf{P}_{1}$ & $\mathbf{P}_{2}$ & $\mathbf{P}_{3}$ & Mean \\
\hline $\mathbf{T}_{1}$ & 6.13 & 6.03 & 5.90 & 6.02 & 4.70 & 4.52 & 4.23 & 4.48 & 36.53 & 36.86 & 25.2 & 32.86 \\
\hline $\mathbf{T}_{2}$ & 6.26 & 6.36 & 6.20 & 6.27 & 5.13 & 4.63 & 4.45 & 4.73 & 39.31 & 37.79 & 36.8 & 37.97 \\
\hline $\mathbf{T}_{3}$ & 7.81 & 7.57 & 5.98 & 7.39 & 5.76 & 5.23 & 4.70 & 5.23 & 50.1 & 47.26 & 32.95 & 43.44 \\
\hline $\mathbf{T}_{4}$ & 8.23 & 8.22 & 6.00 & 7.48 & 6.13 & 5.78 & 5.36 & 5.76 & 54.67 & 54.07 & 34.46 & 47.73 \\
\hline $\mathbf{T}_{5}$ & 7.67 & 7.60 & 6.40 & 7.22 & 5.43 & 4.96 & 4.40 & 4.93 & 35.63 & 33.66 & 30.5 & 33.26 \\
\hline Mean & 7.22 & 7.16 & 6.41 & 6.87 & 5.43 & 5.02 & 4.63 & 5.02 & 43.25 & 41.93 & 31.98 & 38.72 \\
\hline $\begin{array}{l}\text { For comparing the } \\
\text { means of }\end{array}$ & \multicolumn{2}{|c|}{ S.Em \pm} & \multicolumn{2}{|c|}{ CD (5\%) } & \multicolumn{2}{|c|}{ S.Em \pm} & \multicolumn{2}{|c|}{ CD (5\%) } & \multicolumn{2}{|c|}{ S.Em \pm} & \multicolumn{2}{|c|}{ CD (5\%) } \\
\hline $\mathbf{T}$ & \multicolumn{2}{|c|}{0.14} & \multicolumn{2}{|c|}{0.33} & \multicolumn{2}{|c|}{0.04} & \multicolumn{2}{|c|}{0.11} & \multicolumn{2}{|c|}{0.57} & \multicolumn{2}{|c|}{1.68} \\
\hline $\mathbf{P}$ & \multicolumn{2}{|c|}{0.08} & \multicolumn{2}{|c|}{0.25} & \multicolumn{2}{|c|}{0.03} & \multicolumn{2}{|c|}{0.09} & \multicolumn{2}{|c|}{0.44} & \multicolumn{2}{|c|}{1.30} \\
\hline $\mathbf{T} \times \mathbf{P}$ & \multicolumn{2}{|c|}{0.19} & \multicolumn{2}{|c|}{0.57} & \multicolumn{2}{|c|}{0.07} & \multicolumn{2}{|c|}{0.20} & \multicolumn{2}{|c|}{1.00} & \multicolumn{2}{|c|}{2.91} \\
\hline
\end{tabular}


Table.3 Effect of time of pollination and period of pollen storage on germination percentage in brinjal hybrid

\begin{tabular}{|c|c|c|c|c|}
\hline \multirow{3}{*}{ Time of pollination } & \multicolumn{4}{|c|}{ Germination percentage } \\
\hline & \multicolumn{3}{|c|}{ Period of pollen storage } & \multirow[b]{2}{*}{ Mean } \\
\hline & $\mathbf{P}_{1}$ & $\mathbf{P}_{2}$ & $\mathbf{P}_{3}$ & \\
\hline$T_{1}$-Pollination between 6 -7 am & $\begin{array}{c}81.13 \\
(64.24)^{*}\end{array}$ & $\begin{array}{c}79.16 \\
(62.82)\end{array}$ & $\begin{array}{c}75.80 \\
(60.51)\end{array}$ & $\begin{array}{c}78.70 \\
(62.52)\end{array}$ \\
\hline $\mathrm{T}_{2}$-Pollination between 7-8 am & $\begin{array}{c}83.43 \\
(65.96)\end{array}$ & $\begin{array}{c}81.86 \\
(64.78)\end{array}$ & $\begin{array}{c}76.35 \\
(60.93)\end{array}$ & $\begin{array}{c}80.55 \\
(63.80)\end{array}$ \\
\hline$T_{3}$ - Pollination between 8-9 am & $\begin{array}{c}85.13 \\
(67.30)\end{array}$ & $\begin{array}{c}83.76 \\
(63.33)\end{array}$ & $\begin{array}{c}79.89 \\
(63.33)\end{array}$ & $\begin{array}{c}82.93 \\
(65.62)\end{array}$ \\
\hline $\mathbf{T}_{4}$-Pollination between 9-10 am & $\begin{array}{c}88.26 \\
(69.93)\end{array}$ & $\begin{array}{c}85.36 \\
(67.48)\end{array}$ & $\begin{array}{c}79.40 \\
(62.98)\end{array}$ & $\begin{array}{c}84.34 \\
(66.80)\end{array}$ \\
\hline $\begin{array}{l}T_{5} \text {-Pollination between } 10-11 \\
\text { am }\end{array}$ & $\begin{array}{c}80.26 \\
(63.61)\end{array}$ & $\begin{array}{c}78.93 \\
(67.48)\end{array}$ & $\begin{array}{c}77.66 \\
(62.98)\end{array}$ & $\begin{array}{c}78.95 \\
(66.80)\end{array}$ \\
\hline Mean & $\begin{array}{c}83.64 \\
(66.22)\end{array}$ & $\begin{array}{c}81.82 \\
(64.80)\end{array}$ & $\begin{array}{c}77.82 \\
(61.90)\end{array}$ & $\begin{array}{c}81.09 \\
(64.30)\end{array}$ \\
\hline For comparing the means of & \multicolumn{2}{|c|}{ S.Em \pm} & \multicolumn{2}{|c|}{ CD $(5 \%)$} \\
\hline $\mathbf{T}$ & \multicolumn{2}{|c|}{0.38} & \multicolumn{2}{|c|}{1.10} \\
\hline $\mathbf{P}$ & \multicolumn{2}{|c|}{0.29} & \multicolumn{2}{|c|}{0.85} \\
\hline $\mathbf{T} \times \mathbf{P}$ & \multicolumn{2}{|c|}{0.65} & \multicolumn{2}{|c|}{1.91} \\
\hline
\end{tabular}

Period of pollen storage $(\mathrm{P})$ : $\mathrm{P}_{1}$ - Fresh pollen $\mathrm{P}_{2^{-}}$One day old pollen $\mathrm{P}_{3^{-}}$Two day old pollen

* Figures in the parenthesis indicates arcsine transformed values 
Table.4 Effect of time of pollination and period of pollen storage on fruit diameter, 1000 seed weight and Seed yield per plant in brinjal hybrid

\begin{tabular}{|c|c|c|c|c|c|c|c|c|c|c|c|c|}
\hline \multirow[t]{3}{*}{ Time of pollination } & \multicolumn{12}{|c|}{ Period of pollen storage } \\
\hline & \multicolumn{4}{|c|}{ Seedling length $(\mathrm{cm})$} & \multicolumn{4}{|c|}{ Seedling dry weight (mg) } & \multicolumn{4}{|c|}{ Seedling vigour index } \\
\hline & $\mathbf{P}_{1}$ & $\mathbf{P}_{2}$ & $\mathbf{P}_{\mathbf{3}}$ & Mean & $\mathbf{P}_{1}$ & $\mathbf{P}_{2}$ & $\mathbf{P}_{3}$ & Mean & $\mathbf{P}_{1}$ & $\mathbf{P}_{2}$ & $\mathbf{P}_{3}$ & Mean \\
\hline $\mathbf{T}_{1}$ & 15.72 & 14.41 & 14.68 & 14.94 & 13.27 & 12.01 & 11.24 & 12.17 & 1141 & 1010 & 977 & 1042 \\
\hline $\mathbf{T}_{2}$ & 16.17 & 14.25 & 13.32 & 14.58 & 12.94 & 12.32 & 11.66 & 12.3 & 1210 & 1038 & 895 & 1047 \\
\hline $\mathbf{T}_{\mathbf{3}}$ & 17.03 & 16.11 & 15.82 & 16.32 & 17.73 & 10.95 & 12.12 & 13.6 & 1296 & 1199 & 1115 & 1203 \\
\hline $\mathbf{T}_{4}$ & 17.63 & 16.64 & 15.46 & 16.58 & 15.05 & 13.9 & 10.86 & 13.27 & 1391 & 1247 & 1109 & 1249 \\
\hline $\mathbf{T}_{5}$ & 15.78 & 14.93 & 13.22 & 14.64 & 12.96 & 12 & 9.72 & 11.56 & 1183 & 1067 & 917 & 1055 \\
\hline Mean & 16.46 & 15.27 & 14.5 & 15.42 & 14.39 & 12.24 & 11.15 & 12.6 & 1244 & 1112 & 1002 & 1119 \\
\hline $\begin{array}{c}\text { For comparing the } \\
\text { means of }\end{array}$ & \multicolumn{2}{|c|}{ S.Em \pm} & \multicolumn{2}{|c|}{ CD $(5 \%)$} & \multicolumn{2}{|c|}{ S.Em \pm} & \multicolumn{2}{|c|}{ CD (5\%) } & \multicolumn{2}{|c|}{ S.Em \pm} & \multicolumn{2}{|c|}{ CD (5\%) } \\
\hline $\mathbf{T}$ & \multicolumn{2}{|c|}{0.16} & \multicolumn{2}{|c|}{0.49} & \multicolumn{2}{|c|}{0.21} & \multicolumn{2}{|c|}{0.61} & \multicolumn{2}{|c|}{12.04} & \multicolumn{2}{|c|}{35.07} \\
\hline $\mathbf{P}$ & \multicolumn{2}{|c|}{0.13} & \multicolumn{2}{|c|}{0.38} & \multicolumn{2}{|c|}{0.16} & \multicolumn{2}{|c|}{0.47} & \multicolumn{2}{|c|}{9.33} & \multicolumn{2}{|c|}{27.17} \\
\hline $\mathbf{T} \times \mathbf{P}$ & \multicolumn{2}{|c|}{0.29} & \multicolumn{2}{|c|}{0.84} & \multicolumn{2}{|c|}{0.36} & \multicolumn{2}{|c|}{1.05} & \multicolumn{2}{|c|}{20.86} & \multicolumn{2}{|c|}{60.74} \\
\hline
\end{tabular}

Period of pollen storage $(\mathrm{P})$ : $\mathrm{P}_{1^{-}}$- Fresh pollen; $\quad \mathrm{P}_{2}$ - One day old pollen ; $\mathrm{P}_{3^{-}}$Two day old pollen 
It is concluded that the results of this study indicated that in brinjal hybrid seed production, use of either fresh pollen or pollens stored for one day in the refrigerated condition was proved to be more effective for pollination between 9:00 to 10:00 am of emasculated flower buds by recording higher fruit set, fruit retention, seed yield components, germination percentage and vigor index as compared to rest of the treatments.

\section{References}

Basavaraj, N., 1992, Studies on hybrid seed production on brinjal (Solanum melongena L.). M.Sc. (Agri) Thesis, Uni. Agril. Sci, Dharwad.

Chattopadhyay, A., 2000, Effect of emasculation time on fruit set and hybrid seed yield in brinjal under old alluvial zone of West Bengal. $J$. Intera-Academicia, 4(3): 470-473.

Chen, N. C., 2003, Eggplant seed production. Asian Veg. Res. and Develop Center, pp.

10-14.

Chitradevi, L., 2000, Determination of optimal conditions for the production of tomato hybrid seeds. Ph. D. Thesis, Indian Agricultural Research Institute, New Delhi.

Hazra, P., Mandal, J. and Mukhopadhyay, T.
P., 2003, Pollination behaviour and natural hybridization in Solanum melongena $\mathrm{L}$. and utilization of the functional male sterile line, 22: 143146.

Jolli, R. B., 2004, Standardization of hybrid seed production techniques in tomato (Lycopersicon esculentum Mill.). Ph.D Thesis, Uni. Agril. Sci., Dharwad.

Nascimento, W. M., Torres, A. C. and Lima, L. B., 2000, Pollen viability in hybrid production of eggplant under tropical conditions. ISHS, ActaHorti., IX Int. Sym. Timing of Field Production in Vegetable Crops, 607: 1-5.

Padda, D. S. and Singh, J., 1971, Studies on some important aspects of floral biology in chillies. Indian J. Agri. Res., 5(3): 217-218.

Patil, S. D., Desale, S. D. and Badgujar, C. D., 2003, Genetics of yield components in brinjal. Advances in $\mathrm{Pl}$. Sci., 16: 281-86.

Petrova, H. R., Doikova, M. and Popova, D., 1981, Studies on the quality of eggplant seed. Acta Horticulturae, 111: 275-280.

Yogeesha, H. S., Nagaraja, A. and Sharma, S. P., 1999, Pollination studies in hybrid tomato seed production. Seed Sci. and Technol., 27: 115-122.

\section{How to cite this article:}

Veeresha, Shantappa Tirakannanavar, S.M., Dileep Kumar Masuti, R.C. Jagadeesha Ratnakar M. Shet and V. Harshavardhan Gowda. 2018. Effect of Time of Pollination and Period of Pollen Storage on Seed Yield and Quality of Brinjal Hybrid (Solanum melongena L.). Int.J.Curr.Microbiol.App.Sci. 7(07): 1783-1791. doi: https://doi.org/10.20546/ijcmas.2018.707.211 